\title{
Relationship between Ergosterol Concentrations in Wine Yeast and Sugar Fermentation at Different Temperatures*
}

\author{
J.J. Venter ${ }^{1}$, H.J.J. van Vuuren ${ }^{2}$, A. Tromp ${ }^{1}$ and J.H. Randall ${ }^{3}$ \\ 'Viticultural and Oenological Research Institute (VORI), Private Bag X5026, 7600 Stellenbosch \\ ${ }^{2}$ Department of Microbiology and \\ ${ }^{3}$ Department of Biometry, University of Stellenbosch, 7600 Stellenbosch, Republic of South Africa.
}

Submitted for publication: April 1989

Accepted for publication: August 1989

Key words: Ergosterol, wine yeast, fermentation, temperature

\begin{abstract}
The effect of cellular ergosterol on the fermentation ability of four different Saccharomyces cerevisiae wine yeast strains was studied. Fermentations were carried out at three temperatures and ergosterol concentrations determined at six fermentation stages. The lower ergosterol concentrations at the higher temperatures are ascribed to the higher growth rate of the yeast cells resulting in a more rapid dilution of the ergosterol. Growth of yeast during fermentation was linked with the ergosterol content of the cells. The ergosterol concentration of the yeast cells was not directly correlated to specific fermentation rates.
\end{abstract}

The plasma membrane of Saccharomyces cerevisiae is a lipoprotein bilayer structure (Andreasen \& Stier, 1953). The membrane contains a mixture of phospholipids, including sphingolipids, and cardiolipin. In addition, yeast synthesizes and incorporates sterols into its membranes. The principal sterol is ergosterol (Starr \& Parks, 1962; Rattray, Schibeci \& Kidby, 1975; Parks, 1978). Dulaney, Staply \& Simpf (1954) measured ergosterol production in yeast cultures covering 60 species in 20 genera. Most of the cultures produced about $0,1 \%$ of their dry weight as ergosterol, but some strains of Saccharomyces produced $7-10 \%$ ergosterol dry weight; the average in this genus is $2-5 \%$.

The lipid composition affects membrane functions to a great extent. However, the lipid composition of the yeast membrane is affected by culture conditions. Furthermore, mutants with defects in lipid metabolism contain membranes with altered lipid compositions. Growth of Sacch. cerevisiae under anaerobic conditions results in requirements for both a sterol and an unsaturated fatty acid. However, growth rates similar to those found under aerobic conditions can be maintained under anaerobic conditions if the medium is supplemented with ergosterol and oleic or linoleic acid (Haukeli \& Lie, 1976; Watson \& Rose, 1980). The endogenous levels of unsaturated fatty acids and sterols in Sacch. cerevisiae are lowered by dilution as yeast cells multiply under anaerobic conditions in the absence of lipids; growth ceases when the concentration decreases to approximately $25 \%$ of the values obtained under aerobic conditions (Guidici \& Guerzoni, 1982). The limiting value of ergosterol is $1 \mathrm{mgg}^{-1}$ yeast (dry weight) (Aries \& Kirsop, 1977). However, Strydom, Kirschbaum \& Tromp (1982) stated that ergosterol is probably not directly responsible for the formation of new cells, but may be concerned only with the physiological state of the cell, permitting it to maintain a higher level of activity and enabling it to complete fermentation rapidly. Oxygen deficiency during beer fermentation results in restricted yeast growth, reduced yeast viability, slow and incomplete fermentation and changes in beer flavour (Jakobsen \& Thorne, 1980).

Molecular oxygen is required for cyclization of squalene to squalene epoxide and subsequent demethylation of lanosterol to zymosterol (Rattray et al., 1975). A proportion of each sterol exists in a combined form, presumably as fatty acid esters. Zymosterol is present almost entirely in this form (Aries \& Krisop, 1978). According to Bailey \& Parks (1975) the physiological state of the cells reflects the rate of esterification of yeast sterols with long chain fatty acids. A culture growing exponentially on a good carbon source in a rich medium contains low levels of sterol esters. Once sterol intermediates are esterified, they are effectively prevented from being further metabolized to ergosterol (Bailey \& Parks, 1975). Under anaerobic conditions, sterol esters are metabolized to free sterols (Aries \& Kirsop, 1978; Ahvenainen, 1982).

Yeasts containing sterols with an unsaturated side chain at $\mathrm{C}_{17}$ (ergosterol and stigmasterol) are more alcohol tolerant than those containing a saturated side chain (campesterol and cholesterol) (Thomas, Hossack \& Rose, 1978). Hossack \& Rose (1976) suggested that the double bond in the sterol side chain increased stabilization in the distal part of the fatty-acyl chain in contact with the sterol side chain. This increased stabilization could lead to the formation of a more effective barrier against ethanol molecules entering yeast cells which were suspended in ethanol solutions (Thomas et al., 1978). This barrier effect could be even greater if an asymetrical distribution of sterol molecules in the yeast membrane exists. Thus, if the sterol content is low in the plasma membrane, ethanol tolerance will be lower, and ethanol will have a greater effect on the cell metabolism.

The major significance of sterols in yeast is their influence on the dynamic state of membranes (Proudlock et al., 1968). They influence phospholipid-protein interactions, membrane permeability and activity of membrane-bound enzymes

*Part of MSc. thesis presented at the University of Stellenbosch. Promotor: Prof. H.J.J. van Vuuren.

Acknowledgement: The authors wish to thank Professor M.A. Loos for a critical review of the manuscript. 
(Rattary et al., 1975; Ahvenainen, 1982). Parks \& Starr (1963) reported a relationship between sterol biosynthesis and the respiratory capacity of yeast cells.

This study was undertaken to determine how fermentation at different temperatures affects the ergosterol concentration of four wine yeast strains, and to establish whether there is a relationship between the ergosterol concentration and fermentation rate.

\section{MATERIALS AND METHODS}

Yeast strains: Saccharomyces cerevisiae strains WE 452, WE 500, WE 14 and WE 372 from the VORI collection were used.

Medium: The medium of Usseglio-Tomasset, Ciolfi \& Pagliara (1982) was used with $200 \mathrm{gl}^{-1}$ sucrose as carbon source.

Culture conditions: The medium was filter-sterilized and transferred aseptically into glass flasks which had been presterilized with $80 \%$ ethanol and subsequently rinsed twice with sterile distilled $\mathrm{H}_{2} \mathrm{O}$. The inoculum was prepared by inoculating stock cultures of each yeast strain in $1 l$ flasks containing $400 \mathrm{ml}$ medium. Yeast cells were cultured stationary at $25^{\circ} \mathrm{C}$ for 3 days and then transferred into a $10 \mathrm{l}$ flask and again incubated at $25^{\circ} \mathrm{C}$ for 3 days. These cultures were standardised spectrophotometrically at an optical density of 1,0 at $660 \mathrm{~nm}$ and this was then used to inoculate the medium (4\% $\mathrm{v} / \mathrm{v}$ inoculum). Fermentations were carried out in triplicate at $10,15^{\circ} \mathrm{C}$ and $20^{\circ} \mathrm{C}$ in $10 \mathrm{l}$ flasks which contained $8 \mathrm{l}$ medium and were sealed with a bung fitted with a fermentation trap.

Sampling technique: The medium and suspended yeast cells were thoroughly shaken by rotating the fermentation flask prior to sampling. Sampling was done through the fermentation trap by means of $\mathrm{CO}_{2}$ (oxygen-free) pressure (Osumi et al., 1978). Samples $(360 \mathrm{ml})$ were taken at intervals during which the sugar concentration decreased by about $12,5 \mathrm{gl}^{-1}$. The yeast cells were washed twice in distilled $\mathrm{H}_{2} \mathrm{O}$ by centrifugation (13000 g x $10 \mathrm{~min})$. The pellet was finally suspended in $4 \mathrm{ml}$ distilled $\mathrm{H}_{2} \mathrm{O}$ and stored at $-20^{\circ} \mathrm{C}$. The supernatant was stored at $0^{\circ} \mathrm{C}$ until analysis.

Yeast dry mass: Washed yeast cells were dried at $105^{\circ} \mathrm{C}$ to constant mass.

Sugar analysis: The total reducing sugars as $\left(\mathrm{gl}^{-1}\right.$ invert sugar were determined by employing the official methods of the AOAC (Anon, 1975).

Ergosterol analysis: One ml yeast suspension was added to $1 \mathrm{ml}$ distilled $\mathrm{H}_{2} \mathrm{O}$, and the ergosterol concentration determined by the method of Breivik \& Owades (1957) using a Beckman Model 25 spectrophotometer.
Fermentation rate: Fermentation rates $\left(\mathrm{gl}^{-1}\right.$ sugar fermented day ${ }^{-1}$ ) were determined for the intervals 0-24, 13-37, 38-62, 63-87, 88-112 $\mathrm{gl}^{-1}$ and 113-137 $\mathrm{gl}^{-1}$ sugar fermented which corresponded to six fermentation stages. These values were considered to indicate the activity of the yeasts at each fermentation stage and were also used to determine specific fermentation rates (SFR) as gl $^{-1}$ sugar fermented day ${ }^{-1} 100$ $\mathrm{mg}^{-1}$ yeast cells.

Standardization of data: Yeast dry mass and ergosterol concentrations were plotted against sugar concentration. Standardised values corresponding to $12,25,50,75,100 \mathrm{gl}^{-1}$ and $125 \mathrm{gl}^{-1}$ sugar fermented (fermentation stages 1-6) were then obtained from the graphs.

Statistical analysis: A completely randomised experimental design with three replicates was employed. Three measurements were taken at each of the six fermentation stages. Consequently an analysis, taking account of the potential correlations between measurements at the various stages, was performed. The analysis was performed using the REPEATED command of the SAS procedure GLM and the POLYNOMIAL transformation keyword for fermentation stages. The PRINTE option was used to perform a sphericity test, as described in the SAS User's Guide (Anon, 1985). Separate analyses were performed for ergosterol concentration and fermentation rate. A standard VORI factorial statistical software package was used to test significant differences among treatment means (identical fermentation stages). The same program was used to determine correlation coefficients.

\section{RESULTS AND DISCUSSION}

For both variables (ergosterol concentration and fermentation rate) strain $\mathrm{x}$ temperature $\mathrm{x}$ stage interactions were indicated by the multivariate test (the sphericity test was rejected in both cases ) and separate analyses were, therefore, performed for each yeast strain. In the ergosterol concentration analyses by strain, the approximate significance levels (SL) were 0,0018 (WE 14), 0,1598 (WE 372), 0,2423 (WE 452) and 0,3788 (WE 500). The sphericity test was therefore only rejected in the case of WE 14 . In the case of fermentation rate only the WE 500 sphericity test was not rejected (SL $=0$, 1546). The multivariate test performed when the sphericity test was rejected are illustrated in Table 1 for ergosterol concentration in WE 14. The univariate analysis of variance, valid when the conditions for failing to reject the sphericity test are met, is illustrated in Table 2 for WE 372 on the same variable.

TABLE 1

Multivariate analysis of variance over six fermentation stages for WE 14 at three temperatures.

\begin{tabular}{|c|c|c|c|}
\hline $\begin{array}{l}\text { Source of } \\
\text { variation }\end{array}$ & Numerator & $\begin{array}{l}\text { df } \\
\text { Denominator }\end{array}$ & $\begin{array}{l}\qquad \text { Significance Level } \\
\text { (Wilks, Lambda, or Pillai`s trace, or Hotelling-Lawley } \\
\text { trace, or Roy's gratest root) }\end{array}$ \\
\hline Stage & 5 & 2 & 0,0403 \\
\hline Stage $\mathrm{x}$ Temp. (Linear) & 5 & 2 & 0,0360 \\
\hline Stage x Temp. (Quad.) & 5 & 2 & 0,0365 \\
\hline
\end{tabular}


TABLE 2

Unvariate analysis of variance for WE 372 at three temperatures and over six fermentation stages.

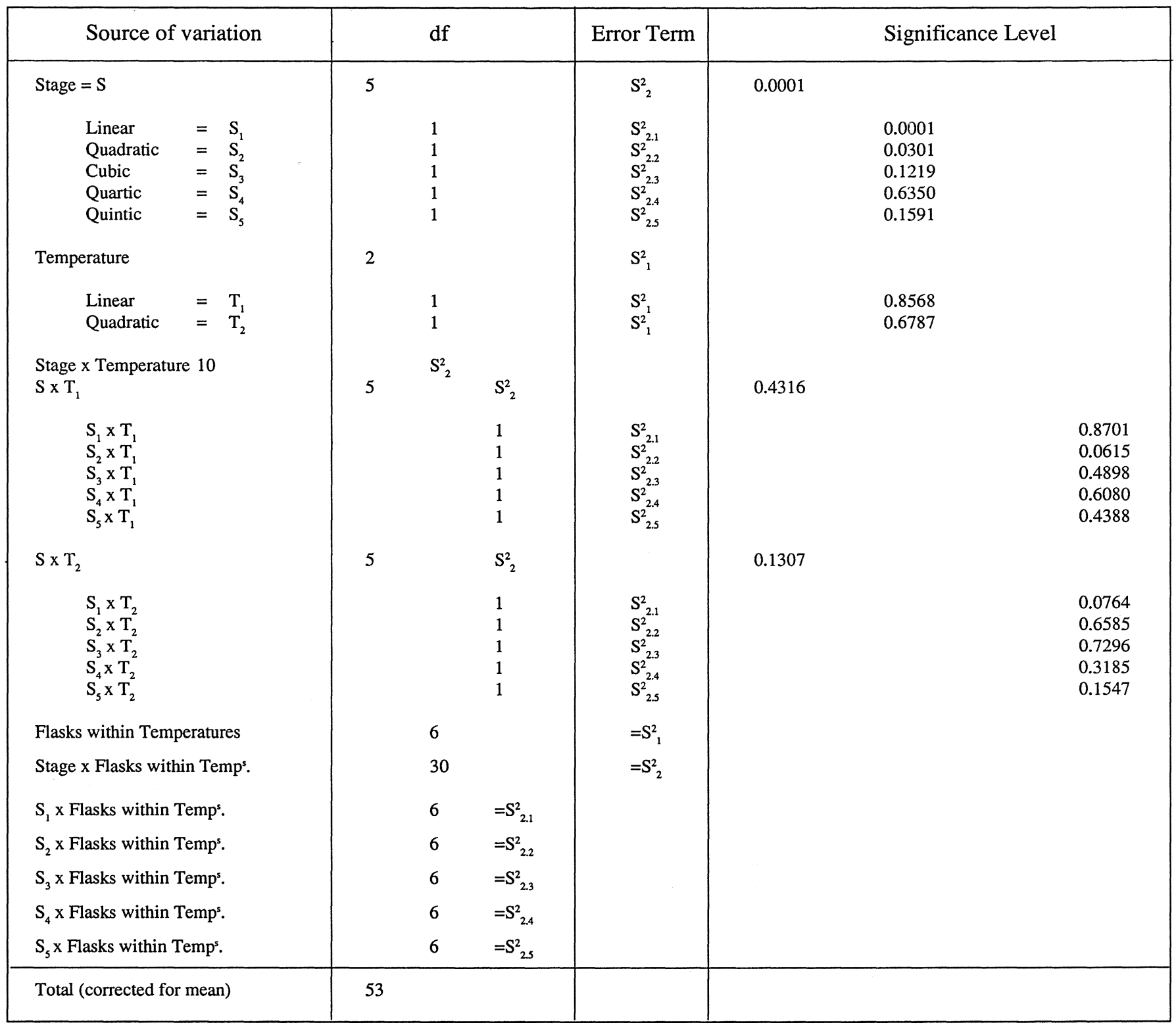

The mean times needed by each of the different yeasts to reach the various fermentation stages are presented in Table 3. At $10^{\circ} \mathrm{C}$ yeast strain WE 500 fermented $125 \mathrm{gl}^{-1}$ sugar in the shortest time, followed by WE 452, WE 14 and WE 372 . At $15^{\circ} \mathrm{C}$ and $20^{\circ} \mathrm{C}$, the fermentation time needed to reach the sixth fermentation stage was similar for strains WE 452 and WE 500, somewhat longer for strain WE 14 and almost twice as long for strain WE 372 . The mean times needed by yeast strain WE 372 to ferment $125 \mathrm{gl}^{-1}$ sugar were $2,28,1,81$ and 1,44 times longer at $10,15^{\circ} \mathrm{C}$ and $20^{\circ} \mathrm{C}$ respectively than those needed by strain WE 500, therefore, strain WE 372 seems to be sensitive to lower fermentation temperatures.

The ergosterol content of the yeast cells decreased during fermentation for all strains (Fig. 1). The rate of decline of ergosterol per $100 \mathrm{mg}$ cells from the first to the sixth fermentation stage differed significantly between the three temperatures for all strains. Yeast ergosterol appears to be an individ- ual characteristic of Sacch. cerevisiae strains as indicated by the temperature $x$ strain $x$ stage interaction. Guidici \& Guerzoni (1982) also concluded that cell ergosterol content is a strain characteristic and proposed that cell ergosterol content of yeast can be used for yeast selection for vinification.

The ergosterol results in Fig. 1 were obtained with no oxygen in the synthetic medium other than that present at the start of fermentation. Andreasen \& Stier $(1953,1954)$ showed that when Sacch. cerevisiae was grown anaerobically in Yeast Nitrogen Base (YNB) medium, a nutritional requirement for an unsaturated fatty acid and a sterol was induced. The addition of Tween 80 , oleic, linoleic and linolenic acid to these anaerobic cultures allowed growth. These findings have been corroborated by other investigators (Alterthum \& Rose, 1973; David \& Kirsop, 1973; Hossack \& Rose, 1976). However, Macy \& Miller (1983) reported that growth does occur in YNB medium in the absence of ergosterol and oleic acid. Our 

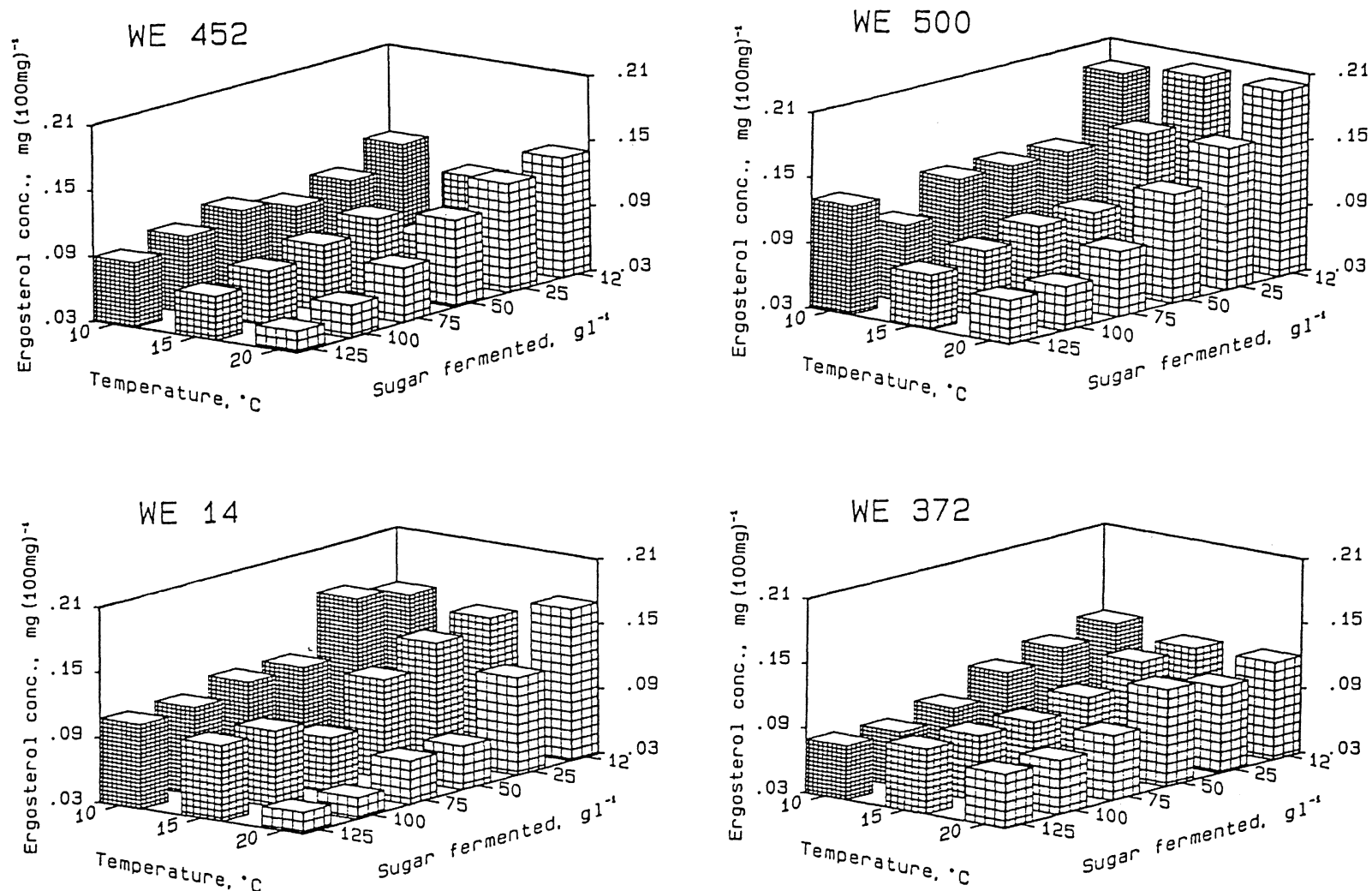

FIGURE 1

Ergosterol concentration in cells of Saccharomyces cerevisiae strains WE 452, WE 500, WE 14 and WE 372 during fermentation at three temperatures.

TABLE 3

The mean time needed for four yeast strains to reach specific fermentation stages at three temperatures.

\begin{tabular}{|c|c|c|c|c|c|c|c|}
\hline \multirow{2}{*}{$\begin{array}{l}\text { Yeast } \\
\text { strain }\end{array}$} & \multirow{2}{*}{$\begin{array}{c}\text { Temperature } \\
\left({ }^{\circ} \mathrm{C}\right)\end{array}$} & \multicolumn{6}{|c|}{ Time(days) } \\
\hline & & $\begin{array}{c}\mathrm{S} 1 \\
12^{\mathrm{a}}\end{array}$ & $\begin{array}{l}S 2 \\
25\end{array}$ & $\begin{array}{l}\text { S3 } \\
50\end{array}$ & $\begin{array}{l}\text { S4 } \\
75\end{array}$ & $\begin{array}{r}\text { S5 } \\
100\end{array}$ & $\begin{array}{r}\text { S6 } \\
125\end{array}$ \\
\hline WE 452 & 10 & 6,43 & 9,73 & 14,73 & 20,10 & 24,13 & 33,03 \\
\hline WE 500 & & 3,30 & 6,27 & 11,80 & 16,03 & 21,77 & 27,90 \\
\hline WE 14 & & 5,17 & 9,17 & 15,13 & 23,77 & 35,53 & 51,40 \\
\hline WE 372 & & 9,03 & 15,77 & 26,67 & 41.70 & 58,10 & 63,75 \\
\hline WE 452 & 15 & 1,73 & 3,20 & 5,17 & 6,80 & 9,10 & 11,93 \\
\hline WE 500 & & 1,93 & 3,30 & 5,17 & 6,80 & 9,10 & 11,67 \\
\hline WE 14 & & 2,07 & 3,17 & 5,30 & 8,07 & 11,43 & 15,53 \\
\hline WE 372 & & 3,07 & 5,27 & 7,50 & 10,40 & 14,87 & 21,07 \\
\hline WE 452 & 20 & 0,80 & 1,57 & 2,87 & 4,00 & 5,37 & 7,37 \\
\hline WE 500 & & 1,00 & 1,83 & 3,10 & 4,27 & 5,60 & 7,17 \\
\hline WE 14 & & 0,98 & 1,80 & 3,03 & 4,47 & 6,17 & 8,68 \\
\hline WE 372 & & 1,33 & 2,37 & 3,87 & 5,30 & 7,50 & 10,33 \\
\hline
\end{tabular}

$S=$ fermentation stage

$\mathrm{a}=$ sugar fermented $\left(\mathrm{gl}^{-1}\right)$ 
results confirmed that Sacch. cerevisiae cells grow under nonaerated conditions in the absence of exogenous sterols and unsaturated fatty acids during the initial stages of fermentation. The yeast dry mass increased considerably over the first three stages, but little or no yeast growth was observed over the final three stages (Table 4).

However, the endogenous levels of these lipids were depleted under these conditions. The ergosterol content of the cells at the fourth stage was between $0,09 \%$ and $0,13 \%$ at $10^{\circ} \mathrm{C}$, between $0,09 \%$ and $0,12 \%$ at $15^{\circ} \mathrm{C}$ and between $0,07 \%$ and $0,09 \%$ at $20^{\circ} \mathrm{C}$ for all four yeast strains (Fig. 1). Further growth of the yeasts in this study could well have been inhibited by a growth-limiting concentration of approximately 0,1\% ergosterol (David \& Kirsop, 1973; Haukeli \& Lie, 1976; Aries \& Kirsop, 1977) as this compound is not produced under anaerobic conditions, as well as by the ethanol in the medium. The lower ergosterol concentrations at the higher temperatures are ascribed to the higher growth rate of the yeast cells resulting in a more rapid dilution of the ergosterol. The decrease in ergosterol content of yeast strain WE 452 in the absence of growth during stages 5 and 6 is surprising and can probably be ascribed to cellular wastage of this sterol. interaction could be simplified to stage $\mathrm{x}$ temperature (linear). In the case of WE 14 the former interaction had $\mathrm{SL}=0,5588$ while the latter had $\mathrm{SL}=0,0014$, while for WE 452 the corresponding values were 0,0542 and 0,0033 respectively. The data and the polynomial equation (that passing through the "treatment" means) were ploted three-dimensionally in Fig. 2. The different patterns indicated the strain $x$ temperature $x$ fermentation stage interactions. 'The fermentation rates of all four yeast strains at similar stages of fermentation decreased with decreasing temperature. The maximum fermentation rates were reached between the second and the fourth fermentation stages with yeast strains WE 452, WE 500 and WE 372 at all three temperatures, but from the first to the third stage with WE 14 (Fig. 2). Yeast strain WE14 was thus the fastest starter among the four strains.

Figure 3 shows that the specific fermentation rates (SFR) decreased as the fermentation proceeded. Higher fermentation temperatures resulted in higher SFR. The SFR were the highest for WE 14 at 15 and $20^{\circ} \mathrm{C}$ during the first two fermentation stages, followed by the SFR of WE 452, WE 500 and WE 372. The SFR of WE 14 decreased drastically as the fermentation proceeed. Strain WE 14 is possibly more sensi-

TABLE 4

Mean dry mass of yeast cells produced by four yeast strains at six fermentation stages at three temperatures.

\begin{tabular}{|c|c|c|c|c|c|c|c|c|c|c|c|c|}
\hline \multirow{3}{*}{$\begin{array}{c}\text { Sugar } \\
\text { fermented } \\
\left(\mathrm{gl}^{-1}\right)\end{array}$} & \multicolumn{12}{|c|}{ Yeast dry mass $\left(\mathrm{mg} \mathrm{ml}^{-1}\right)$} \\
\hline & \multicolumn{3}{|c|}{ WE 452} & \multicolumn{3}{|c|}{ WE 500} & \multicolumn{3}{|c|}{ WE 14} & \multicolumn{3}{|c|}{ WE 372} \\
\hline & $10^{\circ} \mathrm{C}$ & $15^{\circ} \mathrm{C}$ & $20^{\circ} \mathrm{C}$ & $10^{\circ} \mathrm{C}$ & $15^{\circ} \mathrm{C}$ & $20^{\circ} \mathrm{C}$ & $10^{\circ} \mathrm{C}$ & $15^{\circ} \mathrm{C}$ & $20^{\circ} \mathrm{C}$ & $10^{\circ} \mathrm{C}$ & $15^{\circ} \mathrm{C}$ & $20^{\circ} \mathrm{C}$ \\
\hline 12 & 14 & 17 & 21 & 18 & 25 & 32 & 14 & 16 & 16 & 22 & 25 & 25 \\
\hline 25 & 26 & 32 & 40 & 37 & 44 & 49 & 22 & 26 & 26 & 34 & 38 & 41 \\
\hline 50 & 41 & 47 & 53 & 40 & 49 & 56 & 28 & 42 & 50 & 38 & 48 & 54 \\
\hline 75 & 45 & 52 & 55 & 40 & 50 & 58 & 33 & 46 & 57 & 40 & 51 & 60 \\
\hline 100 & 47 & 53 & 55 & 38 & 52 & 63 & 39 & 48 & 55 & 41 & 48 & 59 \\
\hline 125 & 44 & 53 & 55 & 36 & 52 & 65 & 40 & 47 & 55 & 41 & 46 & 54 \\
\hline
\end{tabular}

The analysis of ergosterol by yeast strain showed stage $\mathrm{x}$ temperature interaction in all cases except WE 372. Table 2 shows no significant differences between temperatures and a quadratic curve is sufficient to describe the reduction in ergosterol concentration during fermentation. The pattern of change for the other three strains is one of stage $x$ temperature (quadratic) interaction, i.e. curved responses over temperature which differ depending on the stage involved (Fig. 1).

The analysis of fermentation rate by yeast strain showed similar stage $\mathrm{x}$ temperature (quadratic) interaction, although there was a general tendency suggesting that the nature of the tive to ethanol than the other three strains. The ergosterol concentration of WE 500 at the first fermentation stage (Fig. 1) probably influenced the physiological state of the cell and permitted the cells to maintain higher SFR (although not significant compared to WE 452) at the sixth fermentation stage than the other three strains at all three temperatures (Table 5). These data for strain WE 500 supported the statement of Strydom et al. (1982), viz. that a high ergosterol concentration enables the cells to complete fermentation more rapidly. However, in contrast, no significant difference was found between the ergosterol concentrations of WE 372 and 

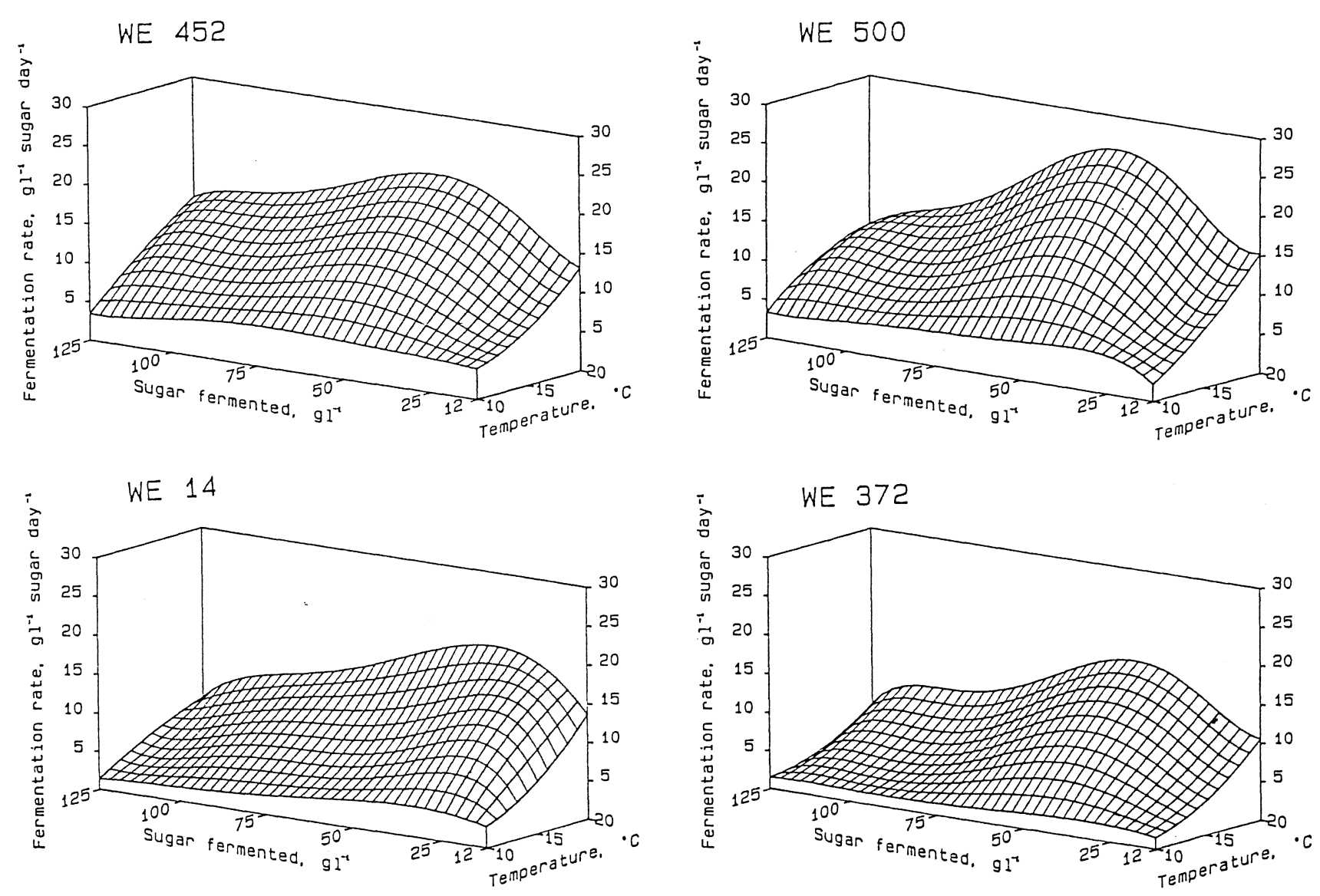

FIGURE 2

Rates of sugar fermentation by Saccharomyces cerevisiae strains WE 452, WE 500, WE 14 and WE 372 at different stages of fermentation at temperatures from 10 tot $20^{\circ} \mathrm{C}$.

WE 500 at $15^{\circ} \mathrm{C}$ and $20^{\circ} \mathrm{C}$, but WE 500 had significantly higher SFR values than WE 372 at the sixth fermentation stage (Tables 5, 6 \& Fig. 3). At $10^{\circ} \mathrm{C}$, strain WE 500 contained the highest cell ergosterol concentration (Table 6) and maintained the highest SFR at the sixth fermentation stage (Table
5). Thus, these conflicting results showed that a high ergosterol concentration alone does not always ensure a high fermentation rate, resulting in a negative correlation $(\mathrm{r}=-$ $0,57 \%$ ) between the SFR and the ergosterol concentration during the sixth fermentation stage.

TABLE 5

Mean specific fermentation rate of four yeast strains at three temperatures during the sixth fermentation stage.

\begin{tabular}{|l|l|l|l|l|}
\hline \multirow{2}{*}{$\begin{array}{l}\text { Temp. } \\
0^{\circ} \mathrm{C}\end{array}$} & \multicolumn{3}{|c|}{ Specific fermentation rate $\left(\mathrm{gl}^{-1}\right.$ sugar day $^{-1}\left(100 \mathrm{mg} \mathrm{cells}^{-1}\right)$} \\
\cline { 2 - 5 } & WE 452 & WE 500 & WE 14 & WE 372 \\
\hline 10 & $7,49 \mathrm{ab}$ & $9,52 \mathrm{bc}$ & $3,49 \mathrm{a}$ & $3,65 \mathrm{a}$ \\
15 & $15,97 \mathrm{def}$ & $18,34 \mathrm{fg}$ & $11,51 \mathrm{bcd}$ & $7,45 \mathrm{ab}$ \\
20 & $19,40 \mathrm{fg}$ & $22,50 \mathrm{~g}$ & $14,96 \mathrm{def}$ & $13,83 \mathrm{cde}$ \\
\end{tabular}

The letters a-g designate groups which are significantly different $(P \leq 0,05)$ 

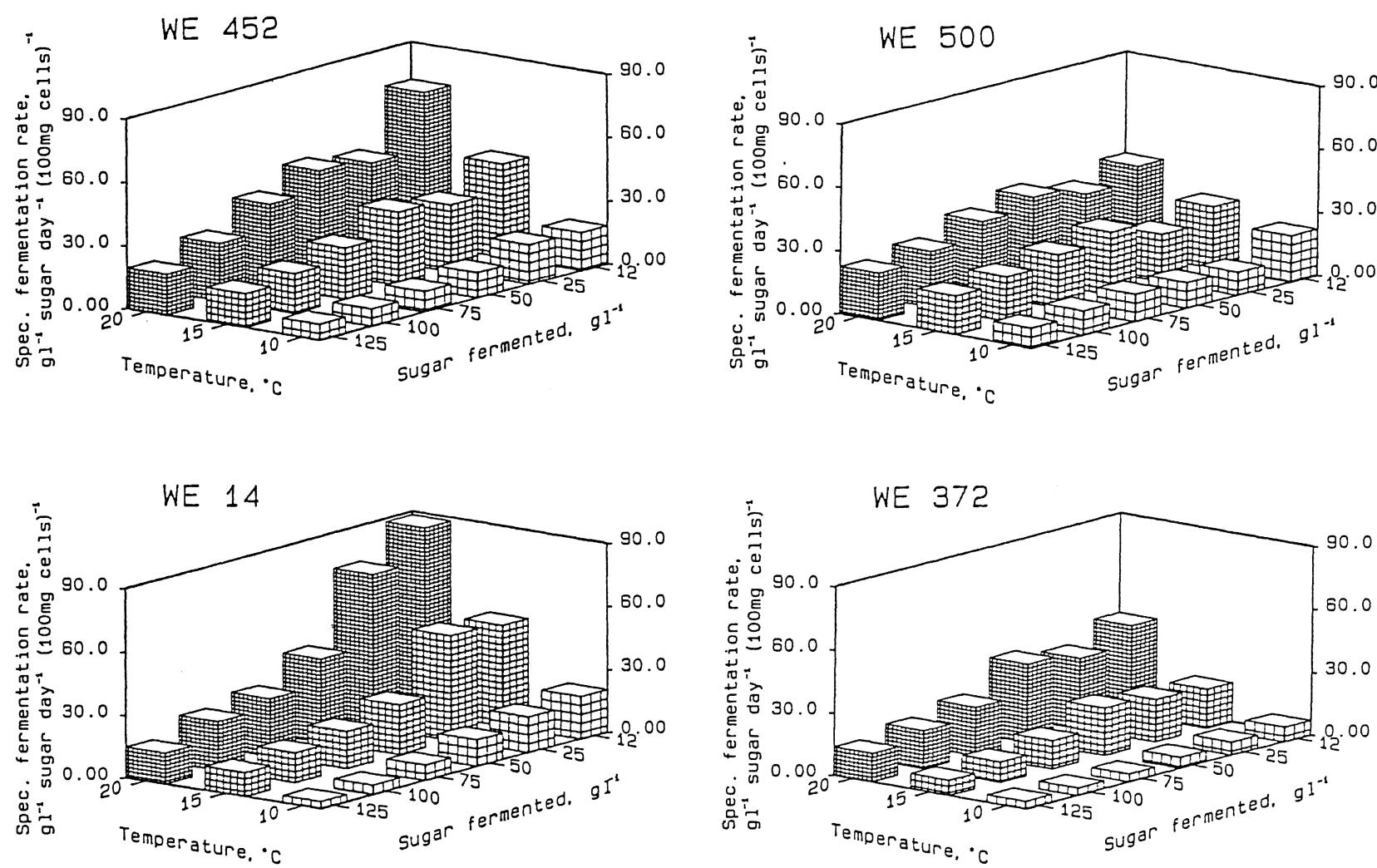

FIGURE 3

Specific fermentation rates of Saccharomyces cerevisiae strains WE 452, WE 500, WE 14 and WE 372 at three temperatures.

TABLE 6

Mean ergosterol concentration of four yeast strains at three temperatures during the sixth fermentation stage.

\begin{tabular}{|c|l|c|c|c|}
\hline \multirow{2}{*}{$\begin{array}{c}\text { Temp. } \\
\left(10^{\circ} \mathrm{C}\right)\end{array}$} & \multicolumn{3}{|c|}{ Ergosterol concentration $\left(\mathrm{mg}(100 \mathrm{mg})^{-1}\right)$} \\
\cline { 2 - 5 } & WE 452 & WE 500 & WE 14 & WE 372 \\
\hline 10 & $0,09 \mathrm{bc}$ & $0,13 \mathrm{~d}$ & $0,10 \mathrm{c}$ & $0,08 \mathrm{bc}$ \\
15 & $0,07 \mathrm{ab}$ & $0,08 \mathrm{bc}$ & $0,10 \mathrm{c}$ & $0,09 \mathrm{bc}$ \\
20 & $0,05 \mathrm{a}$ & $0,07 \mathrm{ab}$ & $0,05 \mathrm{c}$ & $0,08 \mathrm{bc}$ \\
\hline
\end{tabular}

The letters a-d designate groups which are significantly different $(\mathrm{P} \leq 0,05)$

\section{CONCLUSIONS}

During anaerobic growth (fermentation) yeast cellular growth depended mainly on the yeast strain and the thermal conditions during fermentation. Lower ergosterol concentrations at the higher temperatures are ascribed to the higher growth rate of the yeast cells resulting in a more rapid dilution of the ergosterol. The fermentation rates, therefore, cannot be directly related to ergosterol concentration, because of the temperature $\mathrm{x}$ strain $\mathrm{x}$ stage interaction. High ergosterol contents did not always result in high fermentation rates during the later stages of fermentation. It must be borne in mind that this experiment was done in a synthetic medium and the results must still be confirmed in a complex medium such as must. 


\section{LITERATURE CITED}

AHVENAINEN, J., 1982. Lipid composition of aerobically and anaerobically propagated brewer's bottom yeast. J. Inst. Brew. 88, 367-370.

ALTERTHUM, F. \& ROSE, A.H., 1973. Osmotic lysis of sphaeroplasts from Saccharomyces cerevisiae grown anaerobically in media containing different unsaturated fatty acids. J. Gen. Microbiol. 77, 371-383.

ANDREASEN, A.A. \& STIER, T.J.B., 1953. Anaerobic nutrition of Saccharomyces cerevisiae. I. Ergosterol requirement for growth in a defined medium. J. Cell. Comp. Physiol. 41, 23-26.

ANDREASEN, A.A. STIER, T.J.B., 1954. Anaerobic nutrition of Saccharomyce serevisiae. II. Unsaturated fatty acid requirement for growth in a defined medium. J. Cell. Comp. Physiol. 43, 271-281.

ANONYMOUS, 1975. Official Methods of Analysis of the A.O.A.C., 11th ed. Association of Official Analytical Chemists, Washington D.C.

ANONYMOUS, 1985. SAS User's Guide: Statistics, 1985, Version 5 Edition. SAS Institut Inc., Cary, NC.

ARIES, V. \& KIRSOP, B.H., 1977. Sterol synthesis in relation to growth and fermentation by yeasts inoculated at different concentrations. J. Inst. Brew. 83, 220-223.

ARIES, V. \& KIRSOP, B.H., 1978. Sterol biosynthesis by strains of Saccharomyces cerevisiae in the presence and absence of dissolved oxygen. J. Inst. Brew. 84, 118 122.

BAILEY, R.B. \& PARKS, L.W., 1975. Yeast sterol esters and their relationship to the growth of yeast. J. Bacteriol. 124, 606-612.

BREIVIK, O.N. \& OWADES, J.L., 1957. Spectrophotometric semi-microdetermination of ergosterol in yeast. J. Agric. Food Chem. 5, 360-363.

DAVID, M.H. \& KIRSOP, B.H., 1973. Yeast growth in relation to the dissolved oxygen and sterol content of wort. J. Inst. Brew . 79, 20-25.

DUNLANEY, E.L., STAPLY, E.O. \& SIMPF, K., 1954. Ergosterol production by yeasts. Appl. Microbiol. 2, 371-379.

GUIDICI, P.\& GUERZONI, M.E., 1982. Sterol content as a character for selecting yeast strains in enology. Vitis 21, 5-14.

HAUKELI, A.D. \& LIE, S., 1976. Effect of lipids and oxygen on yeast growth and the biosynthesis of acetoin during fermentation. J. Inst. Brew. 82, 161-165.
HOSSACK, J.A. \& ROSE, A.H., 1976. Fragility of plasma-membranes in Saccharomyces cerevisiae enriched with different sterols. J. Bacteriol. 127, 65-75.

JAKOBSEN, M. \& THORNE, R.S.W., 1980. Oxygen requirements of brewing strains of Saccharomyces uvarum (carlsbergensis) - bottom fermentation yeast. J. Inst. Brew. 86, 284-287.

MACY, J.M. \& MILLER, M.W., 1983. Anaerobic growth of Saccharomyces cerevisiae in the absence of oleic acid and ergosterol? Arch. Microbiol. 134, 64-67.

OSUMI, T., TAKETANI, S., KATSUKI, H., KUHARA, T. \& MATSUMOTO, I., 1978. Ergosterol biosynthesis in yeast. J. Biochem. 83, 1213-1227.

PARKS, L.W., 1978. Metabolism of sterols in yeast. CRC. Crit. Rev. Microbiol. 6, 301340.

PARKS, L.W. \& STARR, P.R., 1963. A relationship between ergosterol and respiratory competency in yeast. J. Cell. Comp. Physiol. 61, 61-65.

PROUDLOCK, J.W., WHEELDON, L.W., JOLLOW, D.J. \& LINNANE, A.W., 1968. Role of sterols in Saccharomyces cerevisiae. Biochem. Biophys. Acta 152, 434-437.

RATTRAY, J.B.M., SCHIBECI, A. \& KIDBY, D.K., 1975. Lipids of yeasts. Bacteriol. Rev. 39, 197-231.

STARR, P.R. \& PARKS, L.W., 1962. Some factors affecting sterol formation in Saccharomyces cerevisiae. J. Bacteriol. 82, 1042-1046.

STRYDOM, M., KIRSCHBAUM, A.F. \& TROMP, A., 1982. Ergosterol concentration of several different Saccharomyces cerevisiae yeast strains. S. Afr.J.Enol.Vitic. 3, 23-28.

THOMAS, D.S., HOSSACK, J.A. \& ROSE, A.H., 1978. Plasma-membrane lipid composition and ethanol tolerance in Saccharomyces cerevisiae. Arch. Microbiol. 117, 239-245.

USSEGLIO, TOMASSET, R., CIOLFI, G. \& PAGLIARA, A., 1982. Evaluation de la résistance des levures au dioxyde de soufre. I. Le délai d'action sur le début de la fermentation. O.I.V. 743, 1049.

WATSON, K. \& ROSE, A.H., 1980. Fatty-acyl composition of the lipids of Saccharomyces cerevisiae grown aerobically or anaerobically in media containing different fatty acids. J. Gen. Microbiol. 117, 225-233. 